\title{
Abdominal Mass
}

National Cancer Institute

\section{Source}

National Cancer Institute. Abdominal Mass. NCI Thesaurus. Code C34333.

An abnormal growth in the abdomen. 